\title{
48 時問結核菌遠心管内培養法（抄錄）
}

$\begin{array}{lllllll}\text { 和歌山住友病院 } & \text { 内科医長 } & \text { 医学博士 } & \text { 藤 } & \text { 澤 } & \text { 元 } & \text { 雄 } \\ & \text { 小児科 医 学士 } & \text { 堀 } & \text { 田 } & \text { 敬 } & \text { 夫 } \\ & \text { 細菌学研究室 } & \text { 技師 } & \text { 山下 } & \text { 紀 } & \text { 州 } & \text { 男 }\end{array}$

現在広く用いられて居る結核菌の卵培善基培養法は 検出に長い日数を要する欠点がある. 京大結研で考案 された遠心管内結核菌培養法は48時間で検出され，其 方法る簡易, 経費は低廉, 最も実用的なることを吾々 は追試した。

（材料）当院内科及小坚科入院及外来患者の咯痰を 材料とし. 塗沫標本をチール，ネールゼン氏法で染色 し 100 視野鏡㭘陰性のもの 238例に就て施行した.

（方法）

1. 前述の塗沫鏡検陰性の咯痰 $1.0 \mathrm{cc}$ 宛 4 本のゴム 栓付隇菌遠心管に入れる。

2. 各遠心管に減菌ピペットにて $4 \%$ 节性ソーダ液 $5.0 \mathrm{cc}$ 宛入れ上下に強く振湦して溶解させる.

3. 3000 娗転以上で 20 分間遠心器を使用して分離す る.

（1本だけはこっまでにして集菌法を行う）

4, 残る 3 本はその上清を捨て 沈渣物汇 隇菌蒸溜水 $5.0 \mathrm{cc}$ 加之再 3000 転以上で20分間遠心分離する。

5. 乙かる後其の上清を捨て，沈渣物に培量のキル
ヒナー培養基（家鬼血清を10\%に含有する）をよ く振晹混和した後密栓して $37^{\circ} \mathrm{C}$ の拜卵器内にて 試験管立に垂㨁に培養する。

6. 内1本を 48 時間後に取出し 3000 廻転以上にて 20 分 間遠心沈港し，その沈渣物を染沫染色 100 視野鏡 検する. 若し陰性の場合は72時間後に次の1本を 取出し，同様の検查，これでる陰性の場合比は更 に120時間後に最後の本を検查し，陰性の場合は， 陰性と判定する.

倘対照としては，集菌法及卵基培養法を施行し た. 即ち集菌法は前述の途中で中止せる1本を減 菌蒸溜水で洗滌後チール,ネールゼン氏法で染色 鏡険することとし，又畉培盖基培養法は，キル七 ナ一培養基を混和する直前の洗洲沈渣の1白金耳 宛を2本の卵培養基に培養して挨出率, 検出日数 を比較することにした。

（結論）普通の遠心沈激器を用万れば卵培養基培養 法では26日間も費すのに本法では僅かに 2 日間で立派 に菌の検出判定が出来る最も簡易な方法である. (YK)
大槻菊男博士 御 考 案

大㭇式 胃腸縫合器

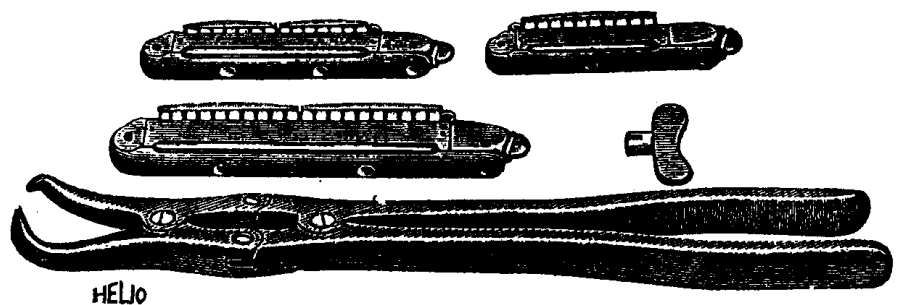

HELIO

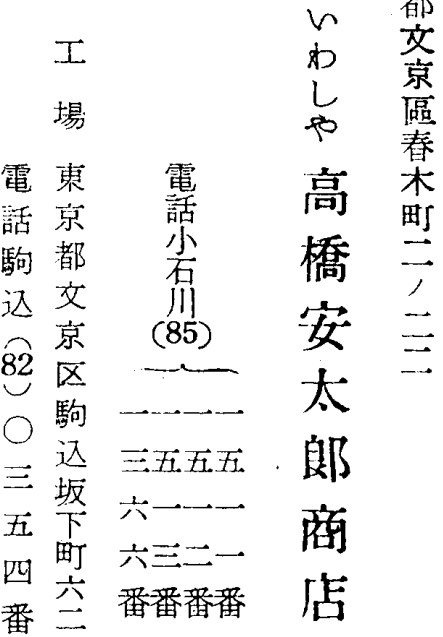

醫學博士 池田三男先生改良御指導 池田式改良グラース氏

人 I 氣胸装 路

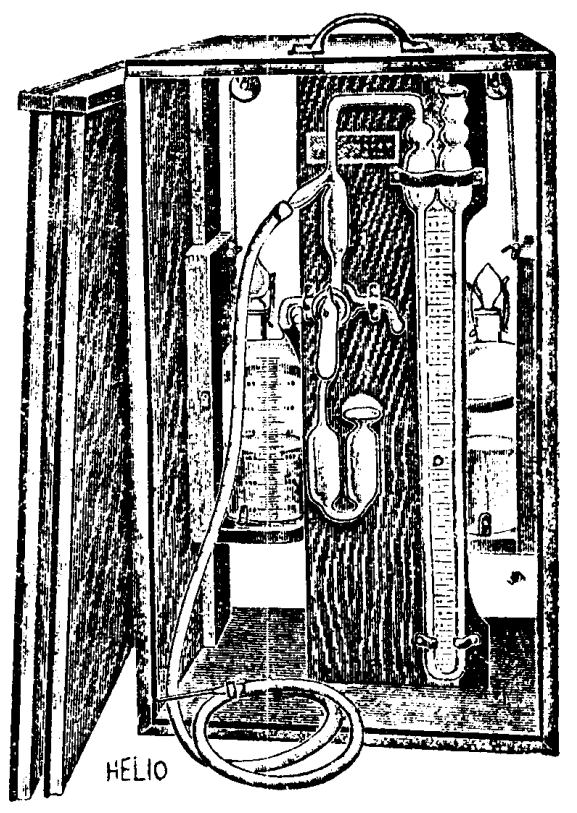

